\title{
Factors Affecting Sustainable Market Acceptance of Residential Microgeneration Technologies. A Two Time Period Comparative Analysis
}

\author{
Spyridon Karytsas ${ }^{1,2, *}$, Ioannis Vardopoulos ${ }^{2, *} *$ and Eleni Theodoropoulou ${ }^{2,3}$ \\ 1 Geothermal Energy Department, Centre for Renewable Energy Sources and Saving (CRES), \\ 19009 Pikermi, Greece \\ 2 Department of Home Economics and Ecology, School of Environment, Geography and Applied Economics, \\ Harokopio University (HUA), 17671 Kallithea, Greece \\ 3 Laboratory of Economic and Social Analysis of the Family and the Consumer, Harokopio University (HUA), \\ 17671 Kallithea, Greece \\ * Correspondence: spkary@cres.gr (S.K.); ivardopoulos@post.com (I.V.)
}

Received: 28 June 2019; Accepted: 19 August 2019; Published: 27 August 2019

\begin{abstract}
On a global scale, the residential sector is responsible for a significant part of consumed energy, of which the major part is dependent upon fossil fuels. A solution for the reduction of fossil fuel use is the application of residential microgeneration technologies. The present study examines the market acceptance factors of such systems in Greece, as well as how these factors change over time, based on real decisions made by consumers. In this context, two surveys applying a common questionnaire were performed in 2012 and 2019 in order to examine the effects of (a) socioeconomic, residence, and spatial characteristics, (b) environmental awareness and behavior, and (c) factors related to consumer behavior, attitudes, and system attribute preferences. Factors affecting the installation of a microgeneration system are gender, age, income, residence type, ownership and size, environmental behavior, use of a subsidy program, as well as views on costs and market-related issues. When evaluating the effect of these factors over time, socioeconomic and residence characteristics, as well as environmental behavior, seem to have a fixed effect to the installation of residential microgeneration systems, with market acceptance fluctuations being related mainly to market conditions, including existing subsidy programs, expectations on fuel prices, and legislation.
\end{abstract}

Keywords: microgeneration technologies; market acceptance; household adoption; socioeconomic characteristics; residence characteristics; environmental behavior; attribute preferences; motivations and barriers; sustainability

\section{Introduction}

On a global scale, the industrial, transport, commercial, and residential sectors demand the vast majority of the energy produced. In particular, the residential sector represents $20 \%$ of total global energy consumption, with projected growth ranging from $0.6 \%$ to $2.1 \%$ per year, contingent on economic and population growth, living standards, building shell improvements, and equipment efficiency [1-3]. Moreover, projections anticipate (despite good intentions) an energy consumption increase by about $60 \%$ by 2040 [1].

Energy production poses a significant risk for public health and the natural environment. Thus, given the accumulative effects arising through generating, transmitting, and using energy, the European Union, in 2008, set the binding objective of producing $20 \%$ of energy from renewables by 2020 [4], which has increased awareness of energy efficiency potential through the use of renewable resources [5]. Subtargets were fixed for each member state, depending on past progress, to meet the common goal. 
Since renewables will play an indispensable role in assisting the EU to meet its energy needs by 2020 and beyond, EU member states, in 2014, entered into a new renewable energy target of $27 \%$ of the EU's final energy consumption by 2030 [6]. In addition, in June 2018, the EU Commission, Parliament, and Council came to a political agreement, introducing a binding renewable energy target for 2030 of $32 \%$ of production, with a clause for an upwards revision by 2023 [7]. With current EU policies it is estimated that renewable energy sources (RES) will account for a share of $24 \%$ by 2030 [8]. It should be noted that policies are mainly formulated based on three factors: the estimate of expected losses associated with the ongoing emissions of carbon dioxide (i.e. climate change effects), the actual coal-based domestic energy price increase in recent years, and the estimated requirements on energy supply security in terms of energy source dependence and progress [9].

Energy consumed by households on the EU scale, in spite of notable reductions, accounts for $26 \%$ [10]. It is worthwhile noting that the overall decrease is mainly due to (i) economic performance, (ii) structural changes and policy improvements in end-use efficiency, and (iii) lower heat consumption due to favorable climatic conditions [11]. The main observation to emerge from the Eurostat data was that for the EU total household energy consumption, $37 \%$ is represented by natural gas, $24 \%$ by electric power, $16 \%$ by renewables and wastes, $12 \%$ by petroleum derivatives and by-products, $8 \%$ by heat recovery, and 3\% by solid fuels [12]. When talking specifically about Greece, residential energy consumption represents about $27.5 \%$ of the final energy consumption [13,14], casting doubt over whether household energy consumption will decline during the Seventh Environment Action Programme period (2014-2020) [15]. Moreover, particularly for Greece, data indicate that energy consumption in the residential sector depends mainly on petroleum products and by-products $(44 \%)$, electricity (27\%), firewood (17\%), and natural gas (5\%) [16]. Known to consume large volumes of energy, heating in Greek housing corresponds to $64 \%$, while cooking corresponds to $17 \%$, electronic appliances to $10 \%$, water-heating to $6 \%$, lighting to $2 \%$, and cooling to $1 \%[16,17]$. Consequently, household heating accounts for a large proportion of the overall energy demand, using mainly fossil fuels [18]. Carbon dioxide emissions and fossil fuel consumption act as key impediments affecting the present and future potential towards achieving sustainable development and security of supply $[19,20]$. With more than half (54\%) of Greece's energy demands being covered by petroleum products alone, the Greek energy sector still heavily relies on imported fossil fuels. Non-interconnected Greek islands, in particular, obtain their electricity primarily from inefficient and costly diesel generators. According to Greek Law 3851 [21], a national target of 20\% RES share in gross final energy consumption by 2020 exceeds the national target of $18 \%$ pursuant to EU Directive 2009/28/EC [4]; however, the overall share of energy from renewables stands at levels close to $15 \%$, as is evident from the latest available progress report [22]. The 2010 Greek National Renewable Energy Action Plan [23] presents the specific trajectory for achieving this objective, including, among others, energy efficiency measures and specific targets for large-scale penetration of RES technologies in the electricity, heating, and cooling share. Currently, on the residential level, the only technology developed is solar thermal, where Greece seems to have a mature market, and therefore, boasts one of the highest installed solar thermal capacities in the EU [24].

To date, a significant number of EU-adopted energy regulations and standards have helped Greece to achieve sufficient energy efficiency regarding new building constructions [25-28]. In particular, Greek Law 4122 [27], together with all the following updated versions (see for example the Hellenic Official Gazette B' 2367/2017 [29]), define the minimum standards for the thermal envelope, electromechanical installations, as well as the design of new buildings (of more than 50 square meters) or existing constructions that will undergo extensive renovations, considering a number of parameters (for example local climatic conditions) [30,31]. In addition, a net metering system for autonomous producers was introduced for the first time in 2014 in Greece, as described in the Hellenic Official Gazette B' 3583/2014 [32]. However, regarding the existing building stock, which admittedly is considered an environmental challenge [33], Greek policy is limited to economic incentives to ease investment barriers and improve cost efficiency, such as window, façades, loft and cavity wall insulations, ventilation, energy efficient light bulbs, solar thermal water-heating systems, conversion to natural gas systems, 
etc. [34]. However, these non-regulatory policy efforts seem inadequate to support micro-renewable technologies in Greece [35], evidently ignoring the potential of reducing the overall energy demand and $\mathrm{CO}_{2}$ emissions with probable effects on the economy [36], towards meeting the energy targets and environmental objectives. This is because, in order to bear witness to a considerable influence on the macro level, a wide-ranging action of individual investments complementing direct and indirect subsidies in such technologies is needed, along with binding regulations requiring long-term upgrades to existing building stock, maximizing occupant health and productivity, using fewer resources, reducing negative environmental impacts, and decreasing life-cycle costs [37].

Thus, with regard to the aforementioned factors on the one hand, and the high-profile debate on climate change [38] and the energy security [39] on the other, decentralized supply and microgeneration seems to be an optimal solution, or even to be necessary, for meeting the environmental objectives with respect to residential energy demand reduction. Decentralized or distributed and microgeneration energy supply refers to generating energy at the place of use. Of course, a range of power generation levels is implied, from regional or communal levels, down to residential complexes and individual households. In particular, recent technological advancements allow homeowners to improve their properties and generate their own electricity and heat through the use of microgeneration technologies. The most commonly installed microgeneration technologies are photovoltaic systems and micro wind turbines for electricity production, and solar thermal systems, biomass boilers, ground source heat pumps (GSHPs), and air source heat pumps (ASHPs) for thermal needs. Now, consumers, or better, "prosumers" (pro-ducer and con-sumer), can claim a new role in the future, decentralized energy market [40]. RES generation growth in households and small commercial establishments, however, depends on the interaction between, on the one hand, the maximization of consumer welfare as the classical economic theory suggests [41], and, on the other hand, consumers' intention to embrace science-driven, environmentally-friendly technological innovation [42], in terms of willingness to pay [9], intention to adopt [43,44], and resistance [37] (within the meaning of a distinct behavioral response [45]).

In recent years there has been considerable interest in consumer views, perspectives, and attitudes towards green energy [46], in terms of both energy-saving activities and renewable energy applications. Various approaches have been put forward to identify the motives and the barriers behind consumer acceptance of RES [47], bringing to light the significance of consumer characteristics (e.g., knowledge, values, beliefs, norms, socioeconomic characteristics, household characteristics, residence characteristics, and geographical location), which affect and ultimately determine energy market mechanisms as endogenous factors [48]. Additionally, a major advance in 2007 [49] helped to clarify social acceptance understanding, distinguishing three dimensions, namely, socio-political acceptance, community acceptance, and market acceptance. Several researchers have also already noted that the economic costs in terms of payback periods, incentives, rebates and grants, the regulatory and market structure, and the technological innovation and awareness, act as exogenous factors for the diffusion of environment-friendly renewables in households [50]. Furthermore, a growing body of literature has examined consumer willingness to pay in order to achieve zero energy consumption through the domestic use of microgeneration renewables [51,52]. Other scholars have examined the preference for, and use of, different available renewables options, even in different social groups [20,53]. Previous studies claim that investment in microgeneration, besides the potential of being an economically-sound manner to reduce energy costs and $\mathrm{CO}_{2}$ emissions, can also initiate positive changes in energy consumption patterns by means of lower levels of consumption and load shifting [54]. However, these findings should be considered as being highly influenced by cultural and socio-economic factors [48], and therefore, understood as being considerably different between nations or even regions within a nation.

Taking all the above into consideration, the present study aims to examine the factors that affect market acceptance of microgeneration technologies, as well as how these factors change over time, through the investigation of real decisions made by Greek consumers, thus contributing to technology 
diffusion on a policy level. In order to identify the market acceptance factors that remain stable, as well as the factors that alter over time, this study compares the results from two different time periods (2012 and 2019), indicating the differences, as well as the causal factors, between them. Since the first bailout agreement for Greece in early 2010, 2012 represented the first year of actual economic, political, and social crisis. The second economic adjustment program was finalized and the seventh austerity package was adopted by the Hellenic Parliament amid two successive elections and nationwide strikes and riots. In late 2018, Greece successfully exits the final bailout program; thus, 2019 is pointing to Greece's return to growth after a ten-year crisis course. In addition, an important fact is the application


program (involving energy efficiency and RES applications in households), within this time period. The factors examined include (a) socioeconomic characteristics, (b) residence characteristics, (c) spatial characteristics, (d) environmental awareness and behavior, and (e) factors related to consumer behavior, attitudes, and system attributes preferences. The contribution of the present study, apart from providing fresh empirical evidence on market acceptance of microgeneration technologies, consists of assessing the importance of the aforementioned groups of factors in a single model. In addition, and as far as the researchers of the present study are aware, there is no previous study applying quantitative methods, comparing the market acceptance of residential microgeneration technologies over time.

In so doing, this research applied a three-step methodological framework. The first step involved survey development and data collection in 2012. The second was a rerun of data collection in 2019, which is considered to be the main novelty of the present research. Lastly, the third step involves data analysis, including a two time period comparison.

\section{Materials and Methods}

\subsection{Survey Development}

A web-based questionnaire was designed in order to conduct the survey. The questionnaire consisted of two essential parts. One section focused on identifying the demographic profile of the sample, while the other included questions aiming to collect information regarding the adoption of residential microgeneration technologies, as well as the factors that affect this process. The developed survey was based on closed-ended questions inviting respondents to answer how they think, feel, and express opinions or intentions about issues which are relevant to them or with which they are familiar, eliciting information regarding knowledge and attitudes, behaviors, and demographics concerning microgeneration technologies. In particular, the questionnaire included questions on:

(a) demographic and socioeconomic characteristics: gender, age, marital status, education level, occupation, annual family income, and location of residence;

(b) residence characteristics: type, ownership, size, year of construction, number and type of residents, participation in household decisions, performed renovations, and use of subsidy program for renovations;

(c) environmental awareness and behavior: 15 questions (plus an attention checking question), with the respondents replying to these questions on a "yes/no" basis; the specific questions were utilized for the development of an environmental awareness and an environmental behavior index;

(d) attitudes and perceptions on factors related to microgeneration systems: a set of 20 questions (plus an attention checking question) related to consumer behavior, preferences, and attitudes regarding residential microgeneration technologies; the factors were evaluated by the respondents on a five-degree Likert scale, from " $1=$ not at all" to " $5=$ very much".

(e) real and hypothetical decisions regarding the installation of different residential microgeneration systems (photovoltaic, solar thermal, micro wind, GSHP, biomass boilers, etc.); in the specific study, the real decisions concerning microgeneration system installation are taken into consideration. 
The questionnaire developed for the 2012 phase was also distributed during the 2019 phase of the research, including only minor modifications, capturing relevant market, financial, etc. changes over time. In both phases, a pilot study was conducted by sending the questionnaire to a small respondent sample. Out of the responses collected during the pilot study, a number of minor significance suggestions were taken into consideration, leading to revisions in the questionnaire; subsequently, the final version was distributed. The final version of the 2019 questionnaire can be found at the reference, in Greek [55].

\subsection{Survey Implementation}

The survey aimed at a random sample of the general population in Greece, with the restriction that respondents should be older than 18 years of age. In both time steps, the questionnaire was distributed through mailing lists; it should be noted that the recipients of the two mailing lists were not the same. At this point, it should be pointed out that the survey involved asking individuals and not households, because it is perceived that people from the same household frequently possess different views on the motives for adoption.

In both time phases, the online questionnaire was distributed through two mailing lists; one from the Center of Renewable Sources and Saving (CRES) and the other from the Harokopio University of Athens (HUA). In the 2012 phase, the questionnaire was distributed in four steps between June and July; accordingly, in the 2019 phase, the four steps were performed between January and February. Due to the methods applied and the sources used to distribute the questionnaire, it is not possible to have an accurate estimation of the response rate. First of all, it is not possible to estimate the number of active email addresses included in the two mailing lists, while there is also no way to evaluate the number of email addresses that never received the link to the questionnaire (being blocked as "spam" email). On the other hand, the invitation accompanying the questionnaire link asked the recipients to forward the link to any contacts they wished to, in the context of snowball sampling; this adds to the fact that it is not possible to estimate the total number of people receiving the questionnaire link.

\subsection{Data Treatment and Analysis}

After both time phases, data collection was followed by the data cleaning and database creation. Data cleaning, in order to capture valuable insights and improve the credibility of the findings, involved the identification and removal of responses from individuals who either didn't match the target audience criteria, didn't answer the questions thoughtfully, or failed to respond to the two instructed response items, i.e. attention checks. The final database included 517 and 427 responses for 2012 and 2019 accordingly.

The SPSS 20 statistical package was used to conduct the statistical analyses. As a first step, a descriptive statistics analysis was performed, including the development of the two environmental indexes; the descriptive results are presented in Section 3.1. The next step involved conducting a Categorical Principal Component Analysis (CatPCA) regarding the factors related to consumer behavior, preferences, and attitudes for specific microgeneration system attributes. This analysis was performed with the aim of grouping the aforementioned factors, and utilizing the results in the following binary logistic models; the methodology and procedures applied are described in detail in Section 3.2. The third step of the statistical analysis involved the development of two binary logistic regression models, one for each time period. The aim of these models was to identify similarities and differences between the two time periods in the context of factors that affect real decisions on residential microgeneration systems installation. The fourth and final step was to perform a regression analysis, based on the findings of the regression models of the previous step, on the pooled data of the two time periods (2012 and 2019). The aim of this analysis was to examine the effect that the time period factor has on the model concerning real decisions on residential microgeneration system installation. The methodology and procedures applied for the binary logistic regression are described in detail in Section 3.3. 


\section{Results}

\subsection{Descriptive Statistics}

The main findings in relation to the socio-economic profile of the two samples are presented in Table 1, including gender, age, education, occupation, and income. In addition, two indexes concerning environmental awareness and environmental behavior are presented. The indexes were developed by summing up all the positive answers of each respondent to questions related to environmental awareness, environmentally-friendly behavior, and energy-saving actions. In the case of environmental awareness, the questions dealt with topics such as knowledge levels for specific energy and environment-related themes, perceptions of climate change, etc., while in the case of environmental behavior, the topics included "green" products, recycling, household energy saving, etc. The maximum value for the environmental awareness index is 5 , while for the environmental behavior index, it is 10 .

Table 1. Demographic and socio-economic characteristics.

\begin{tabular}{|c|c|c|c|c|}
\hline Sample & & 2012 & 2019 & 2011 Census $^{a}$ \\
\hline \multirow{2}{*}{ Gender } & Male & 40.6 & 42.2 & 48.6 \\
\hline & Female & 59.4 & 57.8 & 51.4 \\
\hline Age & mean (SD) & $31.72(9.51)$ & $38.21(10.91)$ & 49.00 (n/a) \\
\hline \multirow{6}{*}{ Education level } & Elementary alum & 0.2 & 0.0 & 27.4 \\
\hline & Middle school graduate & 0.4 & 0.2 & 10.8 \\
\hline & High school degree or equivalent & 15.1 & 13.1 & 29.8 \\
\hline & Vocational training & 4.1 & 10.1 & 10.5 \\
\hline & University degree & 41.8 & 31.9 & 19.0 \\
\hline & Master/Doctorate degree & 38.5 & 44.7 & 2.5 \\
\hline \multirow{6}{*}{ Occupation } & Public or private employed & 45.6 & 59.5 & \multirow{2}{*}{$43.8^{b}$} \\
\hline & Self-employed & 18.0 & 19.9 & \\
\hline & Retired & 2.5 & 2.8 & 28.5 \\
\hline & Student & 22.4 & 12.2 & 3.6 \\
\hline & Homemaker & 0.6 & 0.9 & 14.3 \\
\hline & Unemployed & 10.8 & 4.7 & 9.8 \\
\hline \multirow{5}{*}{ Annual family income } & $0-6000 €$ & 15.5 & 13.8 & \multirow{5}{*}{$\mathrm{n} / \mathrm{a}$} \\
\hline & $6000-12,000 €$ & 20.1 & 18.5 & \\
\hline & $12,000-18,000 €$ & 21.5 & 25.3 & \\
\hline & $18,000-24,000 €$ & 12.8 & 19.2 & \\
\hline & $>24,000 €$ & 30.2 & 23.2 & \\
\hline $\begin{array}{l}\text { Environmental awareness } \\
\text { scale }(\text { max value }=5)\end{array}$ & mean (SD) & $3.38(1.45)$ & $3.36(1.06)$ & $\mathrm{n} / \mathrm{a}$ \\
\hline $\begin{array}{l}\text { Environmental behavior } \\
\text { scale }(\max \text { value }=10)\end{array}$ & mean (SD) & $6.17(1.82)$ & $5.70(1.50)$ & $\mathrm{n} / \mathrm{a}$ \\
\hline
\end{tabular}

${ }^{a}$ taking into account data for population older than 18 years. ${ }^{b}$ including public, private and self-employed.

A profile analysis for the 2012 sample case showed that almost $60 \%$ of respondents were women. The average age of respondents was 32 years. More than $80 \%$ were university educated. The majority of the individuals in the sample were public or private employees, $18 \%$ were self-employed, while approximately $22 \%$ were students; nearly $11 \%$ were unemployed. As to family income per year, at least $30 \%$ reported having an income above $24,000 €$, approximately $20 \%$ somewhat in-between $6000 €$ and $12,000 €$, and a further $20 \%$ somewhere between $12,000 €$ and $18,000 €$. The majority of the 2012 sample resided in privately-owned apartment houses with one or two flatmates on average, with only a small percentage of them being minors or elderly. Nearly $29 \%$ of the participants stated that their dwelling was large, roughly $28 \%$ that was medium or small, while no more than $18 \%$ described it as very large. Lastly, about half of them reported that they had already installed a microgeneration system(s) without making use of the subsidy governmental program. Interestingly, profile-related characteristics of the 2019 sample are scarcely any different from those of the 2012 sample. First of all, a difference 
in age average was observed; however, both samples were of the same generation, i.e., Millennials. An almost 5 percentage point shift from university-educated to technically trained participants was noted. A halfway through decrease in unemployment and studentship status, in favor of the public and private employees, should also be pointed out. And finally, nearly $36 \%$ of the 2019 case respondents reported that they reside with minors, as opposed to no more than $20 \%$ of the participants in the 2012 sample case.

Furthermore, Table 2 includes information concerning the characteristics of the residence: the leading findings concerning location, year of construction, ownership, type, size, number, and type

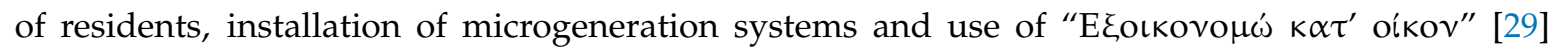
subsidy program.

Table 2. Residence characteristics.

\begin{tabular}{|c|c|c|c|}
\hline Sample & & 2012 & 2019 \\
\hline Year of construction & mean (SD) & $1987(15.65)^{\mathrm{a}}$ & $1988(18.14)^{b}$ \\
\hline \multirow{2}{*}{ Type of housing } & Detached house & 29.8 & 25.5 \\
\hline & Apartment house & 70.2 & 74.5 \\
\hline \multirow{2}{*}{ Property ownership } & Privately owned & 72.7 & 69.8 \\
\hline & Rented & 27.3 & 30.2 \\
\hline \multirow{4}{*}{ Dwelling size } & Small & 26.7 & 14.5 \\
\hline & Medium & 26.7 & 41.0 \\
\hline & Large & 28.8 & 37.2 \\
\hline & Very large & 17.8 & 7.3 \\
\hline $\begin{array}{l}\text { Location density } \\
\left.\text { (population } / \mathrm{km}^{2}\right)\end{array}$ & mean & $\begin{array}{l}12,721.83 \\
(693179)\end{array}$ & $\begin{array}{l}11,084.29 \\
(720129)\end{array}$ \\
\hline Number of residents & mean (SD) & $2.84(1.32)$ & $2.87(1.27)$ \\
\hline \multirow{2}{*}{ Minor(s) residing } & Yes & 19.5 & 35.8 \\
\hline & No & 80.5 & 64.2 \\
\hline \multirow{2}{*}{ Elderly residing (aged 65+) } & Yes & 13.3 & 12.4 \\
\hline & No & 86.7 & 87.6 \\
\hline \multirow{2}{*}{$\begin{array}{l}\text { Installed microgeneration } \\
\text { system }(\mathrm{s})^{\mathrm{c}}\end{array}$} & Yes & 53.8 & 50.6 \\
\hline & No & 46.2 & 49.4 \\
\hline \multirow{2}{*}{ 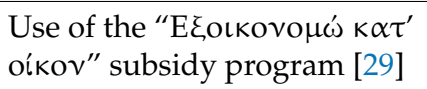 } & Yes & 6.0 & 3.7 \\
\hline & No & 94.0 & 96.3 \\
\hline
\end{tabular}

When referring to factors related to consumer behavior, preferences and attitudes for specific heating system attributes, those evaluated as the most important concerning the residential microgeneration system selection process were (a) functional reliability, (b) system lifetime, (c) operation and maintenance cost, and (d) secure installation, equipment, and operation for the 2012 sample; the same factors were evaluated as the most important also in the 2019 sample, with the difference of having "relative advantages over other systems" instead of "operating and maintenance cost", when talking about the four most important factors. In contrast, the factors that have been evaluated as the least important were common in both surveys: increase of house market value, widespread technology, and ease of installation. In addition, it should be noted that the 2012 sample, compared to that of 2019, attributed higher importance to all the factors under examination, with only two exceptions: (a) government subsidies/tax exemptions, and (b) legislation on the installation process. The largest differences between the two periods were identified for the "expectations for fuel prices" and the “operating and maintenance costs" factors (Figure 1). 


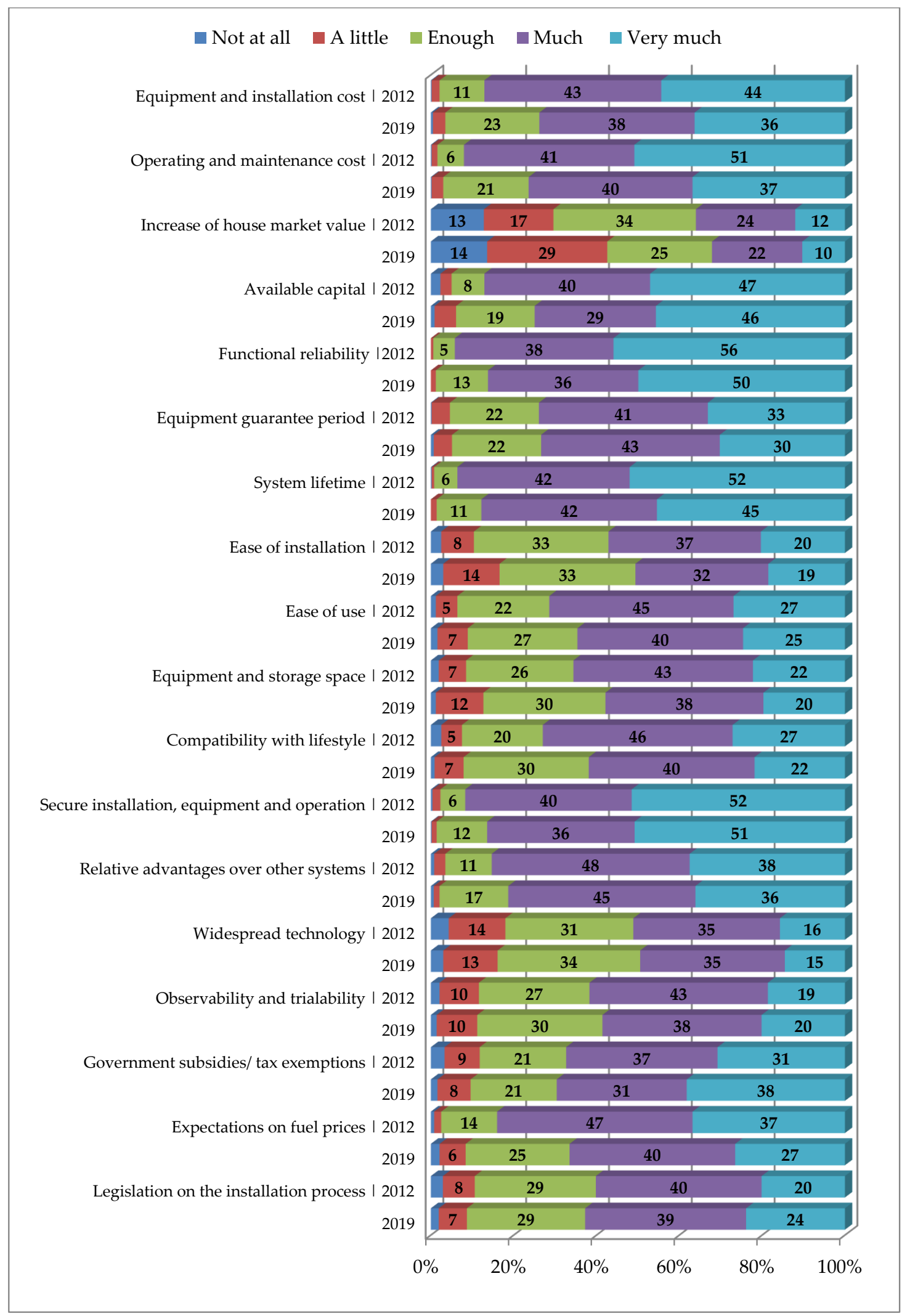

Figure 1. Perceived importance of factors related to consumers' behavior, preferences and attitudes for residential microgeneration technologies. 


\subsection{Categorical Principal Component Analysis for Consumers' Behavior, Preferences and Attitudes for Specific Microgeneration System Attributes}

In terms of classifying the factors related to consumer behavior, preferences, and attitudes for residential microgeneration technologies, CatPCA was applied. CatPCA is in essence the non-linear analogous of PCA [56] and was adopted having in mind that the variables under examination are ordinal. This method analyzes the variables through the principal components model, while transforming the ordinal categorical data into quantitative data in parallel via the optimal scaling technique [57]. In the current study, the numeric valued transformed variables produced through the CatPCA (spline transformations) were input into the PCA for the purpose of performing the suitable rotation method (since rotation is not possible for CatPCA in SPSS). The methodology followed in order to perform the CatPCA is described in detail by Karytsas and Choropanitis [46], including the decisions that must be made in terms of the appropriateness of the sample, the suitability of the included variables, the number of accepted components, the applied rotation method, and the explication of the results.

Firstly, it is necessary to assess the sample size sufficiency; based on the empirical rule, the ratio of observations to variables should be at least 5:1 [58], taking into account the original number of variables of the study, rather than the total contained in the final model [59]. In this study the sample size is $n=944$ (combining both 2012 and 2019 cases) and the variables included are 18, leading to a 52:1 ratio, which is, of course, much higher than the limits set by the rule of thumb. In SPSS, the sample size can be controlled through the Kaiser-Meyer-Olkin (KMO) Measure of Sampling Adequacy, with the sample being satisfactory when the KMO value $>0.50[60,61]$. In the present analysis, the value of $\mathrm{KMO}$ is $0.857>0.50$ (Table 3).

The following step requires examining for potential correlation and multicollinearity between the variables. Bartlett's test of sphericity is applied to test for correlation, with values $<0.05$ [62] being accepted, while multicollinearity is controlled by the determinant of the correlation matrix, with values $>0.00001$ signifying a lack of multicollinearity [61,62]. Furthermore, all diagonal elements of the Anti-Correlation matrix are checked for values greater than 0.50 [61-63], as a means to verify the sample's appropriateness. Actually, after deleting the variables that created multicollinearity issues from the model, it was indicated that patterned relationships existed between the variables, and that no multicollinearity issues occur, while the sample is appropriate (Table 3).

In order to select the number of components comprising the final model, the following criteria are taken into account [46]: (a) the Kaiser Criterion, (b) the Scree Plot, (c) the percentage of the variance explained by the selected components, (d) the values of the communalities, (e) the number of variables included in each component, and (f) the fact that the components should be interpretable. Moreover, it should be noted that the absolute value below which the load factors in each component are not being accepted (cut-off point) plays a significant role for the interpretation of the results; the cut-off point in the specific analysis was set to 0.4 [64].

Furthermore, it should be mentioned that the rotation method selected as the most appropriate was the promax oblique method, based on the concept of achieving "simple structure" [65], or, put differently, with the aim of enhancing the interpretation of the results through clarification of the data arrangement $[66,67]$. Orthogonal rotation methods expect that there is no correlation between the components, while oblique methods assume correlation $[58,68]$. When referring to the social sciences field, a specific relationship between the components is expected, keeping in mind that behavior-based variables hardly ever function independently; thus, in theory, oblique rotation provides more valid results $[56,58,62]$. Additionally, even if theory implies the independence of the components, it should be empirically confirmed with the use of oblique rotation [56]. In practice, the produced factor transformation matrix is utilized with the aim of testing the suitability of the selected rotation method. In particular, an oblique rotation method should be applied if the use of an orthogonal rotation method produces data located outside the diagonal of the table that are not almost symmetric. As this applies in the present analysis, the oblique rotation method was chosen. 
The analysis indicates that the factors related to consumer behavior, attitudes, and preferences for residential microgeneration technology attributes can be divided into four categories; Convenience, Market Conditions, Cost and Performance (Table 3). Each variable has a value $>|0.65|$ in only one component, thereby assisting in reaching "simple structure" [65]. Communality values $\left(\mathrm{h}^{2}\right)$ are presented in the last column of Table 3; these values provide the percentage of variation described by the four components for each specific variable [68]. For instance, $63 \%$ of the variance of the variable "Equipment and storage space" is explained by the four components. When referring to the social sciences fields, typical communality values vary between 0.40 and 0.70 , since it is difficult to attain values $>0.80$ when dealing with real data [58]. Moreover, the percentage of variance that each component represents is displayed in the last row of Table 3 [68]; likewise, the value located at the meeting point of the last row and the last column specifies the total percentage of variation interpreted by the model. Hence, the components of the specific model explain $63.58 \%$ of the variability of the data; the acceptable limit is between $60-70 \%$ [69].

Table 3. Classification of factors related to consumers' behavior, attitudes and system attributes preferences.

\begin{tabular}{|c|c|c|c|c|c|}
\hline \multirow{2}{*}{ Component } & \multicolumn{5}{|c|}{ Component Loading * } \\
\hline & 1 & 2 & 3 & 4 & $\mathbf{h}^{2}$ \\
\hline \multicolumn{6}{|l|}{ CONVENIENCE } \\
\hline Equipment and storage space & 0.812 & - & - & - & 0.630 \\
\hline Compatibility with lifestyle & 0.804 & - & - & - & 0.591 \\
\hline Ease of installation & 0.762 & - & - & - & 0.616 \\
\hline Ease of use & 0.734 & - & - & - & 0.668 \\
\hline \multicolumn{6}{|l|}{ MARKET CONDITIONS } \\
\hline Government subsidies/tax exemptions & - & 0.820 & - & - & 0.604 \\
\hline Expectations on fuel prices & - & 0.706 & - & - & 0.575 \\
\hline Observability and trialability & - & 0.691 & - & - & 0.508 \\
\hline Legislation on the installation process & - & 0.677 & - & - & 0.529 \\
\hline \multicolumn{6}{|l|}{ COST } \\
\hline Equipment and installation cost & - & - & 0.859 & - & 0.753 \\
\hline Available capital & - & - & 0.840 & - & 0.695 \\
\hline Operating and maintenance cost & - & - & 0.705 & - & 0.666 \\
\hline \multicolumn{6}{|l|}{ PERFORMANCE } \\
\hline System lifetime & - & - & - & 0.870 & 0.751 \\
\hline Functional reliability & - & - & - & 0.789 & 0.612 \\
\hline Equipment guarantee period & - & - & - & 0.746 & 0.702 \\
\hline$\%$ of variance explained by each component & 35.365 & 11.644 & 8.698 & 7.875 & 63.583 \\
\hline Bartlett's test of sphericity (significance level) & 0.000 & - & - & - & - \\
\hline Kaiser-Meyer-Olkin measure of sampling adequacy & 0.857 & - & - & - & - \\
\hline Determinant of correlation matrix & 0.008 & - & - & - & - \\
\hline
\end{tabular}

* Only component loadings higher than 0.4 are included in the table.

\subsection{Binary Logistic Regression: Separate Examination of the Two Time Periods}

A binary logistic regression model has been developed, with the two samples (2012 and 2019) being examined separately in order to compare the similarities and differences identified between the two time periods. The dependent variable represents residents' real decisions (has installed/has not installed) towards the installation of residential microgeneration technologies (photovoltaic, solar thermal, micro wind, GSHP, biomass boiler). The explanatory variables taken into account included all the socioeconomic and residence characteristics (Table 1; Table 2), spatial characteristics (Table 2), environmental awareness and behavior (Table 1), as well as consumers' behavior, preferences, and attitudes towards specific heating system attributes expressed as components of the PCA (Table 3). Multicollinearity tests were performed for the independent variables of the binary logistic regression models. The linear regression procedure was applied, since SPSS 20 does not provide collinearity diagnostics for categorical dependent variables of regression procedures [70]. No multicollinearity 
issues exist within the regression models, as in every case, the value of tolerance was $>0.75$, and the value of Variance Inflation Factor (VIF) was $<1.35$ [64,71,72].

Additionally, and in the view of defining the best-fitting regression model, the following metrics were evaluated: (a) -2Log likelihood (-2LL), with smaller values indicating a better fit of the model to the sampling data [73]; (b) the Cox and Snell pseudo $\mathrm{R}^{2}$ goodness of fit test; in a logistic regression values between 0.2 and 0.4 represent an exceptional adaptation [74,75]; (c) the Hosmer-Lemeshow (HL) goodness of fit test, with $\mathrm{p}>0.05$ indicating a suitable model [76]; and (d) the Classification Table presenting the percentage of the accurately classified cases [70]. The corresponding values of the developed model are presented in Table 4.

Table 4. Logistic regression models on real decisions on the installation of residential microgeneration technologies.

\begin{tabular}{|c|c|c|c|c|c|c|c|c|}
\hline & \multirow{2}{*}{ Explanatory Variables } & \multirow{2}{*}{ B } & \multirow{2}{*}{ S.E. } & \multirow{2}{*}{ Wald } & \multirow{2}{*}{ Sig. } & \multirow{2}{*}{$\operatorname{Exp}(B)$} & \multicolumn{2}{|c|}{ 95\% C.I. for EXP(B) } \\
\hline & & & & & & & Lower & Upper \\
\hline \multirow{15}{*}{$\begin{array}{c}2012 \\
\text { sample }\end{array}$} & gender (male) & -0.456 & 0.204 & 5.010 & 0.025 & 0.634 & 0.425 & 0.945 \\
\hline & age & -0.006 & 0.011 & 0.289 & 0.591 & 0.994 & 0.973 & 1.016 \\
\hline & annual_income (upto12000€) & -0.439 & 0.210 & 4.369 & 0.037 & 0.645 & 0.427 & 0.973 \\
\hline & residence_type (detached house) & 0.599 & 0.223 & 7.217 & 0.007 & 1.820 & 1.176 & 2.817 \\
\hline & residence_ownership (self-owned) & 0.941 & 0.227 & 17.226 & 0.000 & 2.563 & 1.643 & 3.998 \\
\hline & residence_size (ordinal) & 0.303 & 0.101 & 8.934 & 0.003 & 1.353 & 1.110 & 1.650 \\
\hline & use_subsidy_program (yes) & 0.155 & 0.414 & 0.140 & 0.709 & 1.167 & 0.518 & 2.629 \\
\hline & environmental_behavior (yes) & 0.112 & 0.054 & 4.376 & 0.036 & 1.119 & 1.007 & 1.243 \\
\hline & factor:market_conditions & -0.120 & 0.103 & 1.341 & 0.247 & 0.887 & 0.724 & 1.087 \\
\hline & factor:cost & -0.287 & 0.112 & 6.565 & 0.010 & 0.751 & 0.603 & 0.935 \\
\hline & Constant & -1.538 & 0.508 & 9.154 & 0.002 & 0.215 & & \\
\hline & $-2 \mathrm{LL}=630.954$ & & & & & & & \\
\hline & $\mathrm{R}^{2}=19.8 \%$ & & & & & & & \\
\hline & HL $\chi^{2}(8)=7.357$ & & & & & & & \\
\hline & Accuracy $=67.5 \%$ & & & & & & & \\
\hline \multirow{15}{*}{$\begin{array}{c}2019 \\
\text { sample }\end{array}$} & gender (male) & -0.377 & 0.216 & 3.043 & 0.081 & 0.686 & 0.449 & 1.048 \\
\hline & age & -0.022 & 0.011 & 4.497 & 0.034 & 0.978 & 0.958 & 0.998 \\
\hline & annual_income (upto12000€) & -0.224 & 0.239 & 0.876 & 0.349 & 0.800 & 0.501 & 1.277 \\
\hline & residence_type (detached house) & 0.454 & 0.254 & 3.181 & 0.074 & 1.574 & 0.956 & 2.591 \\
\hline & residence_ownership (self-owned) & 0.649 & 0.244 & 7.073 & 0.008 & 1.914 & 1.186 & 3.090 \\
\hline & residence_size (ordinal) & 0.297 & 0.148 & 4.016 & 0.045 & 1.345 & 1.007 & 1.798 \\
\hline & use_subsidy_program (yes) & 1.326 & 0.677 & 3.836 & 0.050 & 3.765 & 0.999 & 14.190 \\
\hline & environmental_behavior (yes) & 0.154 & 0.072 & 4.559 & 0.033 & 1.166 & 1.013 & 1.343 \\
\hline & factor:market_conditions & 0.210 & 0.108 & 3.791 & 0.052 & 1.234 & 0.999 & 1.524 \\
\hline & factor:cost & -0.240 & 0.102 & 5.586 & 0.018 & 0.787 & 0.645 & 0.960 \\
\hline & Constant & -1.119 & 0.627 & 3.185 & 0.074 & 0.327 & & \\
\hline & $-2 \mathrm{LL}=536.512$ & & & & & & & \\
\hline & $\mathrm{R}^{2}=16.2 \%$ & & & & & & & \\
\hline & HL $\chi^{2}(8)=11.498$ & & & & & & & \\
\hline & Accuracy $=65.3 \%$ & & & & & & & \\
\hline
\end{tabular}

The best fitting binary logistic model has been developed (Table 4), having applied the aforementioned methodology and metrics. As a first step, a different regression model was developed for each sample (2012 and 2019), including only statistically significant variables ( $a \leq 0.10)$. The next step was to create a common model including all the independent variables from the two models of the first step; thus, not all variables are statistically significant in both cases.

Regression analysis on both samples revealed that women, compared to men, are more likely to install a microgeneration technology in their residence. Moreover, younger individuals are more apt to have microgeneration technology installed for each sample, but this factor was not found to be statistically significant for the 2012 sample. In contrast, respondents with lower family income are less likely to install such a system (not statistically significant in the 2019 model), as well as respondents that attribute higher importance to cost-related attributes of systems of this kind. Still, the results in both cases identify that microgeneration technologies have a much better chance to be installed by individuals with better overall environmental behavior. In addition, regression analysis on the two 
sampled groups showed that in comparison with apartments, microgeneration systems are more likely to be installed in detached houses. Likewise, compared to tenants, individuals owning the property of their residence are more likely to install a microgeneration system. Furthermore, for both cases, it is indicated that the chances are much higher to have a microgeneration system installed in larger dwellings. Regarding the subsidy program [29], the analysis highlighted the existence of a positive effect on the installation of microgeneration systems; however, in the case of the 2012 sample, this factor was not found to be statistically significant. Accordingly, respondents that attribute higher importance to the cost-related attributes of systems of this kind are also less likely to have such a system installed. Additionally, in the 2012 sample case, the market conditions of the microgeneration technology sector were found to have a negative effect to the installation of a microgeneration technology; however, this factor was not found to be statistically significant. On the other hand, in the case of the 2019 sample, market conditions were found to have a positive and statistically significant effect: respondents that attribute higher importance to market conditions and related attributes are more likely to have installed a microgeneration system in their homes. It is worth noting that this is the only factor found to have opposite effects, when comparing the 2012 and the 2019 models. In the 2012 sample case, the factors identified as having the largest effect on the likelihood of having installed a microgeneration system are the type, ownership, and size of the residence, while for the 2019 sample case, the factor with the largest effect was the use of the subsidy program [29], followed by the three aforementioned residence-related factors.

\subsection{Binary Logistic Regression: Pooled Data}

The next step was to perform a binary logistic regression on the pooled data (2012 \& 2019), with the dependent variable being residents' real decisions regarding the installation of residential microgeneration technologies, and including all the independent variables from the separate logistic regression models developed above (Table 4). Additional to the above presented model, a dummy variable indicating the time period (2012 or 2019) was included in the model. Multicollinearity tests were performed, indicating that no multicollinearity issues existed within the regression model; for each independent variable, the value of tolerance was $>0.77$, and the value of the Variance Inflation Factor (VIF) was $<1.29[64,71,72]$. The metrics of the model are presented in the last rows of Table 5.

Table 5. Logistic regression model on real decisions on the installation of residential microgeneration technologies-pooled data (2012 \& 2019).

\begin{tabular}{|c|c|c|c|c|c|c|c|}
\hline \multirow{2}{*}{ Explanatory Variables } & \multirow{2}{*}{ B } & \multirow{2}{*}{ S.E. } & \multirow{2}{*}{ Wald } & \multirow{2}{*}{ Sig. } & \multirow{2}{*}{$\operatorname{Exp}(B)$} & \multicolumn{2}{|c|}{ 95\% C.I. for EXP(B) } \\
\hline & & & & & & Lower & Upper \\
\hline sample (2019) & 0.008 & 0.153 & 0.003 & 0.958 & 1.008 & 0.748 & 1.359 \\
\hline gender (male) & -0.405 & 0.147 & 7.617 & 0.006 & 0.667 & 0.500 & 0.889 \\
\hline age & -0.016 & 0.008 & 4.400 & 0.036 & 0.984 & 0.970 & 0.999 \\
\hline annual_income (upto12000€) & -0.365 & 0.157 & 5.439 & 0.020 & 0.694 & 0.511 & 0.943 \\
\hline residence_type (detached house) & 0.544 & 0.165 & 10.815 & 0.001 & 1.723 & 1.246 & 2.384 \\
\hline residence_ownership (self-owned) & 0.828 & 0.165 & 25.051 & 0.000 & 2.289 & 1.655 & 3.165 \\
\hline residence_size (ordinal) & 0.310 & 0.083 & 13.929 & 0.000 & 1.364 & 1.159 & 1.605 \\
\hline use_subsidy_program (yes) & 0.558 & 0.340 & 2.693 & 0.101 & 1.747 & 0.897 & 3.403 \\
\hline environmental_behavior (yes) & 0.119 & 0.042 & 7.884 & 0.005 & 1.127 & 1.037 & 1.224 \\
\hline factor: market_conditions & 0.042 & 0.074 & 0.319 & 0.572 & 1.043 & 0.902 & 1.205 \\
\hline factor: cost & -0.255 & 0.075 & 11.657 & 0.001 & 0.775 & 0.669 & 0.897 \\
\hline Constant & -1.291 & 0.387 & 11.128 & 0.001 & 0.275 & & \\
\hline \multicolumn{8}{|l|}{$-2 \mathrm{LL}=1169.975$} \\
\hline \multicolumn{8}{|l|}{$\mathrm{R}^{2}=17.4 \%$} \\
\hline \multicolumn{8}{|l|}{$\mathrm{HL} \chi^{2}(8)=4.938$} \\
\hline Accuracy $=66.0 \%$ & & & & & & & \\
\hline
\end{tabular}

The main finding of the regression analysis is that time period, referring of course to the two specific time periods, is not a factor that significantly affects real decisions of consumers concerning the 
installation of residential microgeneration technologies. This means that independently from the time period, the residents would have taken the same decisions in terms of microgeneration technology installation. Additionally, when referring to the pooled data, all socioeconomic and residence related characteristics, environmental behavior, and cost-related aspects were found to have a significant effect on residents' decisions. On the other hand, the two factors that did not have a statistically significant effect in the pooled model were the use of the subsidy program and respondents' opinions regarding market conditions-related attributes (Table 5).

\section{Discussion}

The aim of the present study was to investigate the factors that affect market acceptance of microgeneration technologies, as well as how these factors alter over a period of time, based on real decisions made by Greek consumers. In this context, it should be noted that nearly half of the respondents stated that they had installed microgeneration systems in their homes. It should nevertheless be pointed out that Greece is recognized as one of the leading countries in the use of solar systems for sanitary hot water production (low level temperatures, $55-80^{\circ} \mathrm{C}$ ), presenting one of the highest ratios in the installed solar thermal collector area per capita [77].

In terms of the time-dimension comparison of the determining factors, it was indicated that socioeconomic and residence characteristics, as well as environmental behavior, seem to have a fixed effect over time on the installation of residential microgeneration systems. The main factors that cause fluctuations of market acceptance of such systems over time are related to market conditions, including existing subsidy programs, expectations for fuel prices, and legislation relevant to the installation process. Furthermore, keeping in mind that the factor of time (comparison between 2012 and 2019) was not found to have a significant effect on market adoption, and in combination with the status of Greece during the last decade (economic recession), it could be indicated that the subsidy program, as well as other market-oriented practices, balanced consumer decisions towards the adoption of microgeneration systems.

Logistic regression analysis provides evidence for significant links among the ten factors. Regarding the demographic characteristics, gender is a statistically significant factor, since it appears that women are more likely to have decided to install a microgeneration system. This result is not surprising, since the gender-specific matters studied regarding small-scale RES have shown that women play an active role in energy supply and consumption at the household level [78]. Notwithstanding, women are more environmentally concerned and fearful of climate change [79]; this may perhaps be explained by the perception that they will be affected the most [80], or that as mothers, they have a greater role in conserving the environment for future generations [81]. Thus females are more ecologically conscious, are more likely to take eco-friendly purchasing decisions [82,83], or support renewables development $[84,85]$.

Moreover, age is a factor affecting the installation of residential microgeneration technologies, at least for the 2019 sample, since the analysis found that younger individuals are more apt to have installed a microgeneration technology. Indeed, this finding is consistent with a number of studies showing that attitudes towards microgeneration technologies vary across age groups [86]. For instance, Leenheer et al. [87] found that older people have lower intentions to generate their own energy, while the findings of Karytsas and Theodoropoulou [88] indicate that younger people are more likely to be aware of these energy forms. This could perhaps be explained by the fact that younger people are in favor and more open to innovative, small-scale renewable energy systems, compared with older homeowners, who often exhibit great resistance. Or it could be explained by differences in financial position, given that pensioners are likely to have lower incomes. Whilst there are a number of possible causalities, no solid agreement about this complicated issue was found in the literature.

Furthermore, the empirical results suggest that Greeks with a more than $12,000 €$ annual income who live in self-owned, detached buildings are more likely to have installed a microgeneration system in their homes. Thus, annual income below $12,000 €$ negatively relates to the possibility of someone 
having installed a residential microgeneration system, apparently related to the initial capital needed for such an installation. This result is in agreement with findings of previous studies, indicating that microgeneration installations are affected by higher incomes [89], and the type of residence (i.e., being easier to install in detached houses) [90].

The household budget also relates to the residence ownership status significance role, regarding the initial capital needed for installing microgeneration technologies. In addition, it is more probable that someone will pursue a residential energy upgrade investment if they own the property they live in, as reported for German [89,91] and British [92] households. Considering that property owners are less likely to move, this makes them more inclined to make a long-term investment, such as the installation of a microgeneration system, in terms of adequate payback period for either own funds, loan or subsidies, not only in order to save energy, and therefore money, but also to add value to their property/investment [93]. This is a common issue when dealing with residential energy efficiency investments, referred to as the landlord/tenant dilemma [94]. Heiskanen and Matschoss [95] have highlighted that new financial and organizational solutions have to be found for the diffusion of building-scale RES systems when considering multifamily buildings and low-income households, rather than the auspicious market of middle-class, owner-occupied, single-family homes.

As a further matter, evidence of the current analysis suggests that installed microgeneration technologies are more common in larger houses. This could be due to a variety of reasons [96], such as the available space in larger properties own or the increased energy and heating consumption demand, or even the higher annual residents' income.

Next, the results pointed out that those having installed a microgeneration system are more likely to have taken advantage of the state subsidy opportunity, implying that the existing governmental support is somewhat effective in promoting domestic microgeneration systems. The current subsidy program is a mixture of subsidy and no-interest loans, depending on the tenants' income [34]. This result comes as no surprise if not considered collectively [46,97]. Besides, subsidies efficiency has been studied before, proving that individuals are more likely to proceed with upgrading their residence energy efficiency using microgeneration systems when rebates are offered, as reported for the cases of Sweden [98], Italy [99], and the United States [100]. Thus, the government should consider, after providing more information to the public about the domestic microgeneration systems, further increasing the subsidiaries budget [101]. At the same time, this outcome also supports the finding suggesting that cost-related issues are negatively related to the possibility of someone having installed a residential microgeneration system. In particular, for the scope of this study, cost-related attributes concern equipment and installation costs, available capital, and operating and maintenance costs (see Table 3). The finding indicates that cost was a barrier and had persisted over the years, even if microgeneration system installation has become less expensive, despite the fact that subsidies have reduced the total budget need. This finding is consistent with the wider literature and the status quo in other countries; Palm and Tengvard [47] reported that Swedish households rejected small-scale photovoltaic panel (PV) and micro wind turbine installation because of financial considerations, Balcombe et al. [42] pointed out that British consumers were not willing to pay extra for the environmental benefits that microgeneration technologies offered, Jacksohn et al. [98] noted that German household investments in PV and solar thermal systems were mainly driven by economic factors, while Graziano and Gillingham [102] indicated that installation and operation cost were important factors for the installation of PV systems in American (Connecticut) households. Besides, as Palm [103] has noted for the case of PV adoption in Sweden, cost was a barrier persisting over the years, although installation became cheaper due to lower product costs and the application of subsidy schemes.

However, and here lies the most significant finding of this study, the introduction of subsidies (as previously discussed), the widely shared expectations that fuel prices would remain on a very high level (as noted by Tsaur and Lin [104], electricity price trends affect consumer acceptance of microgeneration systems), the regulatory framework regarding the installation procedure as amended and now valid (as previously discussed), as well as the better adaptation of the companies to market 
requirements (referring to observability and trialability of new technologies), have clearly contributed to the shift observed over the last years, making individuals considering the aforementioned market conditions more likely to have installed microgeneration technologies in their residences.

Furthermore, the environmental behavior index was found to have a statistically significant effect. Tenants having better environmental behavior are more likely to have a microgeneration system installed in their home. This finding is in accordance with previous studies, and in contrast to others; indicatively, Crago and Chernyakhovskiy [100] noted the importance of pro-environmental preferences as a predictor of solar PV demand for the United States market, while Michelsen and Madlener [105] indicated that environmental protection was a key driver for the installation of RES-based residential heating appliances in German dwellings. In contrast, Schaffer and Brun [89] stated that German households' ecological attitudes hardly affected the investment decisions concerning small-scale PV installations. In any case, this could imply that broader environmentally-conscious behavior could stimulate awareness of microgeneration technologies, considering that individuals with such a life approach are more likely to have an interest in information regarding microgeneration technologies.

Apart from new empirical evidence concerning the residential microgeneration technologies market acceptance determining factors, this study's results also offer several implications for policy makers and marketers. The importance of socioeconomic and residence characteristics, environmental behavior, and market and cost aspects are certainly valuable in terms of relevant policies and marketing, as carefully designed measures can be planned based on this information. Indeed, the results are significant to policymakers, as they highlight the importance of the subsidy program and improvements of market conditions. Policies improving market conditions in terms of initial cost reduction, legislative frameworks, and awareness of these technologies may foster the diffusion of these systems. In any case, innovative business models aiming multifamily buildings and low-income households are necessary in order to open the range of the market potential. For example, low initial cost PV systems have been provided to the mass market in the United States through the third-party PV ownership practice [106]. Additionally, a wider range of the population could have the opportunity to install microgeneration systems though community investments [107].

Nonetheless, a number of limitations that might have influenced the obtained results have been identified in the present paper. Perhaps the most significant limitation of the study is that the sample is not completely representative of the general population of Greece, given that the survey was conducted exclusively via an online questionnaire. In particular, and based on the data of the 2011 Greek National Census [108] presented in Table 1, it is evident that there is an overrepresentation of highly-educated people and the middle-aged, working generation. Be that as it may, the sample could nonetheless lead to particular findings which could be used for debate or further studies $[88,109]$.

Another possible discrepancy concerning the questionnaire is that the 2019 survey included some minor modifications, capturing relevant market and financial changes over time, as well as slight amendments in wording, compared to the questionnaire which was developed and distributed in 2012. An additional alteration between the two questionnaires was that the recent one also included two instructed response items, i.e. attention checks. One last alteration in relation to the two distributed questionnaires concerns the environmental awareness and environmental behavior indexes, as the total number and content of the questions used to develop them were slightly different. Despite these weaknesses, the authors believe that this work is still a thorough basis for drawing conclusions, on the effect of the factors affecting the residential installation of a microgeneration system, towards decisive guidance in policymaking over time in a European country.

Further research could include an examination of the factors affecting market acceptance of each different microgeneration technology, going a step further in relation to the present study which investigates microgeneration systems in general, without differentiating among particular technologies. An additional subject of interest would be to take into account not only installers and non-installers, but a third category as well, i.e., consumers that have not installed, but have the intention of doing so. Finally, the same theme, i.e., the examination of factors affecting microgeneration system installation 
over time, could be investigated in the context of the commercial sector. All this proposed research could assist policy makers in identifying the best policies in terms of the diffusion of microgeneration systems.

Author Contributions: Conceptualization, S.K. and I.V.; methodology, S.K. and I.V.; data curation, S.K. and I.V.; investigation, S.K.; formal analysis, S.K.; writing-original draft preparation, S.K. and I.V.; visualization, S.K. and I.V.; validation, S.K. and E.T.; supervision, S.K. and E.T.; project administration, S.K. and E.T.; writing-review \& editing, S.K.

Funding: This research received no external funding.

Conflicts of Interest: The authors declare no conflict of interest.

\section{References}

1. Conti, J.; Holtberg, P.; Diefenderfer, J.; LaRose, A.; Turnure, J.; Westfall, L. International Energy Outlook 2016; United States Energy Information Administration: Washington, DC, USA, 2016.

2. Kampelis, N.; Tsekeri, E.; Kolokotsa, D.; Kalaitzakis, K.; Isidori, D.; Cristalli, C. Development of Demand Response Energy Management Optimization at Building and District Levels Using Genetic Algorithm and Artificial Neural Network Modelling Power Predictions. Energies 2018, 11, 3012. [CrossRef]

3. Kontogiorgos, P.; Chrysanthopoulos, N.; Papavassilopoulos, G.P. A Mixed-Integer Programming Model for Assessing Energy-Saving Investments in Domestic Buildings under Uncertainty. Energies 2018, 11, 989. [CrossRef]

4. European Parliament; Council of the European Union. Directive 2009/28/EC of the European Parliament and of the Council of 23 April 2009 on the Promotion of the Use of Energy from Renewable Sources and Amending and Subsequently Repealing Directives 2001/77/EC and 2003/30/EC; Official Journal of the European Union: Brussels, Belgium, 2009.

5. Nanaki, E.A.; Xydis, G.A. Deployment of Renewable Energy Systems: Barriers, Challenges, and Opportunities. In Advances in Renewable Energies and Power Technologies; Yahyaoui, I., Ed.; Elsevier: Amsterdam, The Netherlands, 2018; pp. 207-229. [CrossRef]

6. European Commission. Communication from the Commission to the European Parliament, the Council, the European Economic and Social Committee and the Committee of the Regions. A Policy Framework for Climate and Energy in the Period from 2020 to 2030; European Commission: Brussels, Belgium, 2014.

7. European Commission. Europe Leads the Global Clean Energy Transition: Commission Welcomes Ambitious Agreement on Further Renewable Energy Development in the EU; European Commission: Brussels, Belgium, 2018.

8. European Commission; International Renewable Energy Agency. Renewable Energy Prospects for the European Union; European Commission: Brussels, Belgium, 2018.

9. Scarpa, R.; Willis, K. Willingness-to-Pay for Renewable Energy: Primary and Discretionary Choice of British Households' for Micro-Generation Technologies. Energy Econ. 2010, 32, 129-136. [CrossRef]

10. Agency European Environmental. Final Energy Consumption by Sector and Fuel; European Union: Copenhagen, Denmark, 2019.

11. Moreau, V.; Neves, C.A.D.O.; Vuille, F. Is Decoupling a Red Herring? The Role of Structural Effects and Energy Policies in Europe. Energy Policy 2019, 128, 243-252. [CrossRef]

12. Eurostat. Energy Consumption in Households; European Commission: Luxembourg, 2018.

13. Koroneos, C.; Polyzakis, A.; Xydis, G.; Stylos, N.; Nanaki, E. Exergy Analysis for a Proposed Binary Geothermal Power Plant in Nisyros Island, Greece. Geothermics 2017, 70, 38-46. [CrossRef]

14. Eurostat. Final Energy Consumption by Sector; European Commission: Luxembourg, 2019.

15. European Parliament; Council of the European Union. Decision No 1386/2013/EU of the European Parliament and of the Council of 20 November 2013 on a General Union Environment Action Programme to 2020 'Living Well, within the Limits of Our Planet' Text with EEA Relevance; Official Journal of the European Union: Brussels, Belgium, 2013.

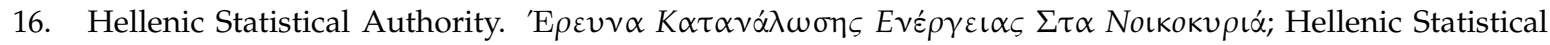
Authority: Piraeus, Greece, 2013.

17. Karytsas, S. An Empirical Analysis on Awareness and Intention Adoption of Residential Ground Source Heat Pump Systems in Greece. Energy Policy 2018, 123, 167-179. [CrossRef] 
18. Sifakis, N.; Savvakis, N.; Daras, T.; Tsoutsos, T.; Sifakis, N.; Savvakis, N.; Daras, T.; Tsoutsos, T. Analysis of the Energy Consumption Behavior of European RES Cooperative Members. Energies 2019, 12, 970. [CrossRef]

19. Vardopoulos, I. Multi-Criteria Decision-Making Approach for the Sustainable Autonomous Energy Generation through Renewable Sources. Studying Zakynthos Island in Greece. Environ. Manag. Sustain. Dev. 2018, 7, 52-84. [CrossRef]

20. Vardopoulos, I. Multi-Criteria Analysis for Energy Independence from Renewable Energy Sources Case Study Zakynthos Island, Greece. Int. J. Environ. Sci. Dev. 2017, 8, 460-465. [CrossRef]

21. Accelerating the Development of Renewable Energy Sources to Deal with Climate Change and Other Regulations Addressing Issues under the Authority of the Ministry of Environment, Energy and Climate Change. Greek Law 3851. 2010.

22. Hellenic Ministry of Environment \& Energy. Fourth Progress Report on the Promotion and Use of Energy from Renewable Sources in Greece; Hellenic Ministry of Environment \& Energy: Athens, Greece, 2018.

23. Hellenic Ministry of Environment Energy \& Climate Change. Hellenic National Renewable Energy Action Plan; Hellenic Ministry of Environment Energy \& Climate Change: Athens, Greece, 2010.

24. Goula, M.A.; Charisiou, N.D. The Greek Energy System and the Lack of Renewable Energy Micro-Generation Schemes. In Proceedings of the 11th International Conference on the Protection and Restoration of the Environment, Thessaloniki, Greece, 3-6 July 2012.

25. Generation of Electricity Using Renewable Energy Sources and High-Efficiency Cogeneration of Electricity and Heat and Miscellaneous Provisions. Greek Law 3468. 2006.

26. Measures to Reduce Energy Consumption in Buildings. Greek Law 3661. 2008.

27. Energy Performance of Buildings-Transposition of Directive 2010/31/EU. Greek Law 4122. 2013.

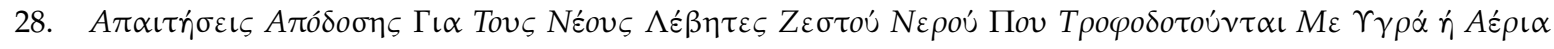

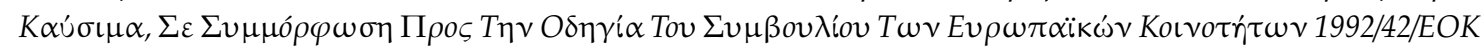

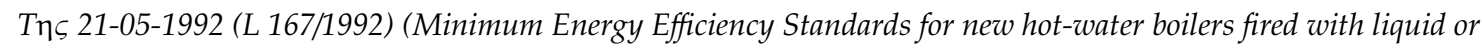
gaseous fuels); Presidential Decree 335; Hellenic Parliament: Athens, Greece, 1993.

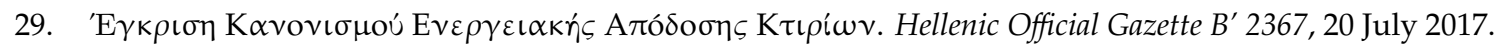

30. Balaras, C.; Dascalaki, E.; Gaglia, A.; Droutsa, P.; Kontoyiannidis, S. An Overview of the New Hellenic Regulation on the Energy Performance of Buildings (KENAK). In 3rd International Conference on Renewable Energy Sources and Energy Efficiency; Michaelides, I., Charalambides, E., Eds.; Cyprus Chamber of Commerce and Industry: Nicosia, Cyprus, 2011. [CrossRef]

31. Dascalaki, E.G.; Balaras, C.A.; Gaglia, A.G.; Droutsa, K.G.; Kontoyiannidis, S. Energy Performance of Buildings-EPBD in Greece. Energy Policy 2012, 45, 469-477. [CrossRef]

32. Installation of RES Plants by Autonomous Producers under a Net-Metering Scheme. Hellenic Official Gazette $B^{\prime}$ 3583, 31 December 2014.

33. Gaglia, A.G.; Dialynas, E.N.; Argiriou, A.A.; Kostopoulou, E.; Tsiamitros, D.; Stimoniaris, D.; Laskos, K.M. Energy Performance of European Residential Buildings: Energy Use, Technical and Environmental Characteristics of the Greek Residential Sector-Energy Conservation and $\mathrm{CO}_{2}$ Reduction. Energy Build. 2019, 183, 86-104. [CrossRef]

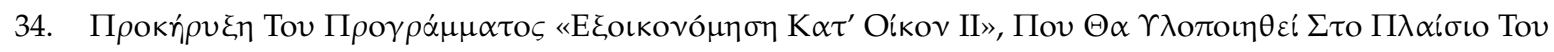
Е $\Sigma$ ПА 2014-2020 (Annoucement of the "save energy at home" subsidy program, implemented in the framework of the NSRF 2014-2020). Hellenic Official Gazette B' 756, 2 March 2018.

35. Giannini, E.; Moropoulou, A.; Maroulis, Z.; Siouti, G. Penetration of Photovoltaics in Greece. Energies 2015, 8, 6497-6508. [CrossRef]

36. Vardopoulos, I.; Konstantinou, Z. Study of the Possible Links Between CO2 Emissions and Employment Status. Sustain. Dev. Cult. Tradit. J. 2016, 1, 100-112. [CrossRef]

37. Claudy, M.C.; Driscoll, A.O.; Garcia, R.; Mullen, M.; Garcia, R.; Mullen, M. Exploring Antecedents of Consumer Resistance Towards Microgeneration Technologies in Ireland. In Proceedings of the 2nd Annual Social Marketing Conference, Galway, Ireland, 4 June 2010.

38. Sapountzaki, K. Athens Facing Climate Change: How Low Perceptions and the Economic Crisis Cancel Institutional Efforts. In Smart, Resilient and Transition Cities; Galderisi, A., Colucci, A., Eds.; Elsevier: Berlin, Germany, 2018; pp. 125-134. [CrossRef] 
39. Mitoula, R.; Abeliotis, K.; Vamvakari, M.; Gratsani, A. Sustainable Regional Development through the Use of Photovoltaic (PV) Systems. The Case of the Thessaly Region. In Proceedings of the World Renewable Energy Congress-Sweden, Linköping, Sweden, 8-13 May 2011. [CrossRef]

40. Romanovsky, G.; Xydis, G.; Mutale, J. Participation of Smaller Size Renewable Generation in the Electricity Market Trade in UK: Analyses and Approaches. In Proceedings of the IEEE PES Innovative Smart Grid Technologies Conference Europe, Manchester, UK, 5-7 December 2011. [CrossRef]

41. Sardianou, E.; Genoudi, P. Which Factors Affect the Willingness of Consumers to Adopt Renewable Energies? Renew. Energy 2013, 57, 1-4. [CrossRef]

42. Balcombe, P.; Rigby, D.; Azapagic, A. Motivations and Barriers Associated with Adopting Microgeneration Energy Technologies in the UK. Renew. Sustain. Energy Rev. 2013. [CrossRef]

43. Karytsas, S.; Theodoropoulou, E. Public Awareness and Willingness to Adopt Ground Source Heat Pumps for Domestic Heating and Cooling. Renew. Sustain. Energy Rev. 2014, 34, 49-57. [CrossRef]

44. Karytsas, S.; Theodoropoulou, E. Factors That Influence Public Awareness and Willingness to Adopt Ground Source Heat Pump (GSHP) Systems for Domestic Heating and Cooling in Greece. In Proceedings of the 2nd PERL International Conference, Berlin, Germany, 19-20 March 2012.

45. Kleijnen, M.; Lee, N.; Wetzels, M. An Exploration of Consumer Resistance to Innovation and Its Antecedents. J. Econ. Psychol. 2009, 30, 344-357. [CrossRef]

46. Karytsas, S.; Choropanitis, I. Barriers against and Actions towards Renewable Energy Technologies Diffusion: A Principal Component Analysis for Residential Ground Source Heat Pump (GSHP) Systems. Renew. Sustain. Energy Rev. 2017, 78, 252-271. [CrossRef]

47. Palm, J.; Tengvard, M. Motives for and Barriers to Household Adoption of Small-Scale Production of Electricity: Examples from Sweden. Sustain. Sci. Pract. Policy 2011, 7, 6-15. [CrossRef]

48. Islam, T.; Meade, N. The Impact of Attribute Preferences on Adoption Timing: The Case of Photo-Voltaic (PV) Solar Cells for Household Electricity Generation. Energy Policy 2013, 55, 521-530. [CrossRef]

49. Wüstenhagen, R.; Wolsink, M.; Bürer, M.J. Social Acceptance of Renewable Energy Innovation: An Introduction to the Concept. Energy Policy 2007, 35, 2683-2691. [CrossRef]

50. Sidiras, D.K.; Koukios, E.G. Solar Systems Diffusion in Local Markets. Energy Policy 2004, 32, $2007-2018$. [CrossRef]

51. Su, W.; Liu, M.; Zeng, S.; Štreimikienè, D.; Baležentis, T.; Ališauskaitė-Šeškienè, I. Valuating Renewable Microgeneration Technologies in Lithuanian Households: A Study on Willingness to Pay. J. Clean. Prod. 2018, 191, 318-329. [CrossRef]

52. Karytsas, S.; Polyzou, O.; Karytsas, C. Factors Affecting Willingness to Adopt and Willingness to Pay for a Residential Hybrid System That Provides Heating/Cooling and Domestic Hot Water. Renew. Energy 2019, 142, 591-603. [CrossRef]

53. Navratil, J.; Picha, K.; Buchecker, M.; Martinat, S.; Svec, R.; Brezinova, M.; Knotek, J. Visitors' Preferences of Renewable Energy Options in "Green" Hotels. Renew. Energy 2019, 138, 1065-1077. [CrossRef]

54. Allen, S.R.; Hammond, G.P.; McManus, M.C. Prospects for and Barriers to Domestic Micro-Generation: A United Kingdom Perspective. Appl. Energy 2008, 85, 528-544. [CrossRef]

55. Survey. Available online: https://forms.gle/vT1D8aSHnW5Sac1w6 (accessed on 27 August 2019).

56. Matsunaga, M. How to Factor-Analyze Your Data Right: Do's, Don'ts, and How-to's. Int. J. Psychol. Res. 2010, 3, 97-110. [CrossRef]

57. Gifi, A. Nonlinear Multivariate Analysis; John Wiley \& Sons: Hoboken, NJ, USA, 1990.

58. Costello, A.B.; Osborne, J.W. Best Practices in Exploratory Factor Analysis: Four Recommendtions for Getting the Most From Your Analysis. Pract. Assess. Res. Eval. 2005, 10, 1-9.

59. Tabachnick, B.G.; Fidell, L.S. Using Multivariate Statistics, 5th ed.; Pearson Allyn \& Bacon: Upper Saddle River, NJ, USA, 2007.

60. Kaiser, H.F. An Index of Factorial Simplicity. Psychometrika 1974, 39, 31-36. [CrossRef]

61. Yong, A.G.; Pearce, S. A Beginner's Guide to Factor Analysis: Focusing on Exploratory Factor Analysis. Tutor. Quant. Methods Psychol. 2013, 9, 79-94. [CrossRef]

62. Field, A. Discovering Statistics Using SPSS: Introducing Statistical Method, 3rd ed.; Sage Publications: Thousand Oaks, CA, USA, 2009.

63. Koostra, G.J. Exploratory Factor Analysis: Theory and Application; University of Groningen Press: Groningen, The Netherlands, 2004. 
64. Hair, J.F.; Black, W.C.; Babin, B.J.; Anderson, R.E.; Tatham, R.L. Multivariate Data Analysis; Prentice Hall: Upper Saddle River, NJ, USA, 1998.

65. Thurstone, L.L. Multiple-Factor Analysis; a Development and Expansion of the Vectors of Mind; University of Chicago Press: Chicago, IL, USA, 1947.

66. Yaremko, R.M.; Harari, H.; Harrison, R.C.; Lynn, E. Handbook of Research and Quantitative Methods in Psychology: For Students and Professionals; Lawrence Erlbaum Associates: Hillsdale, NJ, USA, 1986.

67. Bryant, F.B.; Yarnold, P.R. Principal Components Analysis and Confirmatory Factor Analysis. In Reading and Understanding Multivariate Statistics; Grimm, L.G., Yarnold, P.R., Eds.; American Psychological Association: Washington, DC, USA, 1995; pp. 99-136.

68. Brown, J.D. Choosing the Right Number of Components or Factors in PCA and EFA. Shiken JALT Test. Eval. SIG Newsl. 2009, 13, 20-25.

69. Beaumont, R. An Introduction to Principal Component Analysis \& Factor Analysis Using SPSS 19 and R (Psych Package). Factor Anal. Princ. Compon. Anal. (PCA) 2012, 24, 8-9.

70. IBM Support. Sensitivity and Specificity in Logistic Regression Classification Table; IBM: Armonk, NY, USA, 2011.

71. Menard, S.W. Applied Logistic Regression Analysis; Sage Publications: Thousand Oaks, CA, USA, 1995.

72. O'Brien, R.M. A Caution Regarding Rules of Thumb for Variance Inflation Factors. Qual. Quant. 2007, 41, 673-690. [CrossRef]



74. McFadden, D. Quantitative Methods for Analyzing Travel Behaviour of Individuals: Some Recent Developments. In Behavioural Travel Modelling; Hensher, D.A., Stopher, P.R., Eds.; Croom Helm: London, UK, 1979; pp. 279-318.

75. Domencich, T.; McFadden, D.L. Urban Travel Demand: A Behavioral Analysis; North-Holland Publishing: Amsterdam, The Netherlands, 1996.

76. Lemeshow, S.; Hosmer, D.W. A Review of Goodness of Fit Statistics for Use in the Development of Logistic Regression Models. Am. J. Epidemiol. 1982, 115, 92-106. [CrossRef]

77. Drosou, V.; Tsekouras, P.; Kosmopoulos, P.; Dimoudi, A.; Papadopoulos, A. Concentrating Solar Thermal Systems: Perspectives for Greece. In Proceedings of the 5th International Conference on Renewable Energy Sources and Energy Efficiency, Nicosia, Cyprus, 5-6 May 2016.

78. Nelson, S.; Kuriakose, A. Gender and Renewable Energy: Entry Points for Women's Livelihoods and Employment; Climate Investment Funds: Washington, DC, USA, 2017.

79. Kellstedt, P.M.; Zahran, S.; Vedlitz, A. Personal Efficacy, the Information Environment, and Attitudes toward Global Warming and Climate Change in the United States. Risk Anal. 2008, 28, 113-126. [CrossRef]

80. Viscusi, W.K.; Zeckhauser, R.J. The Perception and Valuation of the Risks of Climate Change: A Rational and Behavioral Blend. Clim. Chang. 2006, 77, 151-177. [CrossRef]

81. Lutzenhiser, L. Social and Behavioral Aspects of Energy Use. Annu. Rev. Energy Environ. 1993, 18, $247-289$. [CrossRef]

82. Lee, K. Gender Differences in Hong Kong Adolescent Consumers' Green Purchasing Behavior. J. Consum. Mark. 2009, 26, 87-96. [CrossRef]

83. Zavali, M.; Theodoropoulou, H. Investigating Determinants of Green Consumption: Evidence from Greece. Soc. Responsib. J. 2018, 14, 719-736. [CrossRef]

84. Greenberg, M. Energy Sources, Public Policy, and Public Preferences: Analysis of US National and Site-Specific Data. Energy Policy 2009, 37, 3242-3249. [CrossRef]

85. Sovacool, B.K.; Valentine, S.V.; Jain Bambawale, M.; Brown, M.A.; de Fátima Cardoso, T.; Nurbek, S.; Suleimenova, G.; Li, J.; Xu, Y.; Jain, A.; et al. Exploring Propositions about Perceptions of Energy Security: An International Survey. Environ. Sci. Policy 2012, 16, 44-64. [CrossRef]

86. Willis, K.; Scarpa, R.; Gilroy, R.; Hamza, N. Renewable Energy Adoption in an Ageing Population: Heterogeneity in Preferences for Micro-Generation Technology Adoption. Energy Policy 2011, 39, 6021-6029. [CrossRef]

87. Leenheer, J.; de Nooij, M.; Sheikh, O. Own Power: Motives of Having Electricity without the Energy Company. Energy Policy 2011, 39, 5621-5629. [CrossRef]

88. Karytsas, S.; Theodoropoulou, H. Socioeconomic and Demographic Factors That Influence Publics' Awareness on the Different Forms of Renewable Energy Sources. Renew. Energy 2014, 71, 480-485. [CrossRef] 
89. Schaffer, A.J.; Brun, S. Beyond the Sun-Socioeconomic Drivers of the Adoption of Small-Scale Photovoltaic Installations in Germany. Energy Res. Soc. Sci. 2015, 10, 220-227. [CrossRef]

90. Balta-Ozkan, N.; Yildirim, J.; Connor, P.M. Regional Distribution of Photovoltaic Deployment in the UK and Its Determinants: A Spatial Econometric Approach. Energy Econ. 2015, 51, 417-429. [CrossRef]

91. Dharshing, S. Household Dynamics of Technology Adoption: A Spatial Econometric Analysis of Residential Solar Photovoltaic (PV) Systems in Germany. Energy Res. Soc. Sci. 2017. [CrossRef]

92. Keirstead, J. Behavioural Responses to Photovoltaic Systems in the UK Domestic Sector. Energy Policy 2007, 35, 4129-4141. [CrossRef]

93. Watson, J.; Sauter, R.; Bahaj, B.; James, P.; Myers, L.; Wing, R. Domestic Micro-Generation: Economic, Regulatory and Policy Issues for the UK. Energy Policy 2008, 36, 3095-3106. [CrossRef]

94. Ástmarsson, B.; Jensen, P.A.; Maslesa, E. Sustainable Renovation of Residential Buildings and the Landlord/Tenant Dilemma. Energy Policy 2013, 63, 355-362. [CrossRef]

95. Heiskanen, E.; Matschoss, K. Understanding the Uneven Diffusion of Building-Scale Renewable Energy Systems: A Review of Household, Local and Country Level Factors in Diverse European Countries. Renew. Sustain. Energy Rev. 2017, 75, 580-591. [CrossRef]

96. Caird, S.; Roy, R. Adoption and Use of Household Microgeneration Heat Technologies. Low Carbon Econ. 2011, 1, 61-70. [CrossRef]

97. Karytsas, S.; Kostakis, I. Barriers and Diffusion Actions of Residential Ground Source Heat Pump Systems in Greece: An Ordered Regression Model Analysis. In Proceedings of the 2nd Economics of Natural Resources and the Environment: Climate Change Conference (ENVECON), Volos, Greece, 31 October 2014.

98. Jacksohn, A.; Grösche, P.; Rehdanz, K.; Schröder, C. Drivers of Renewable Technology Adoption in the Household Sector. Energy Econ. 2019, 81, 216-226. [CrossRef]

99. Alberini, A.; Bigano, A. How Effective Are Energy-Efficiency Incentive Programs? Evidence from Italian Homeowners. Energy Econ. 2015, 52, S76-S85. [CrossRef]

100. Crago, C.L.; Chernyakhovskiy, I. Are Policy Incentives for Solar Power Effective? Evidence from Residential Installations in the Northeast. J. Environ. Econ. Manag. 2017, 81, 132-151. [CrossRef]

101. Jeong, G. Assessment of Government Support for the Household Adoption of Micro-Generation Systems in Korea. Energy Policy 2013, 62, 573-581. [CrossRef]

102. Graziano, M.; Gillingham, K. Spatial Patterns of Solar Photovoltaic System Adoption: The Influence of Neighbors and the Built Environment. J. Econ. Geogr. 2015, 15, 815-839. [CrossRef]

103. Palm, J. Household Installation of Solar Panels-Motives and Barriers in a 10-Year Perspective. Energy Policy 2018, 113, 1-8. [CrossRef]

104. Tsaur, R.-C.; Lin, Y.-H. Exploring the Consumer Attitude of Building-Attached Photovoltaic Equipment Using Revised Technology Acceptance Model. Sustainability 2018, 10, 4177. [CrossRef]

105. Michelsen, C.C.; Madlener, R. Switching from Fossil Fuel to Renewables in Residential Heating Systems: An Empirical Study of Homeowners' Decisions in Germany. Energy Policy 2016, 89, 95-105. [CrossRef]

106. Drury, E.; Miller, M.; Macal, C.M.; Graziano, D.J.; Heimiller, D.; Ozik, J.; Perry, T.D., IV. The Transformation of Southern California's Residential Photovoltaics Market through Third-Party Ownership. Energy Policy 2012, 42, 681-690. [CrossRef]

107. Funkhouser, E.; Blackburn, G.; Magee, C.; Rai, V. Business Model Innovations for Deploying Distributed Generation: The Emerging Landscape of Community Solar in the U.S. Energy Res. Soc. Sci. 2015, 10, 90-101. [CrossRef]

108. Hellenic Statistical Authority. Census, Hellenic Population-Housing; Hellenic Statistical Authority: Piraeus, Greece, 2011.

109. Berrens, R.P.; Bohara, A.K.; Jenkins-Smith, H.; Silva, C.; Weimer, D.L. The Advent of Internet Surveys for Political Research: A Comparison of Telephone and Internet Samples. Polit. Anal. 2003, 11, 1-22. [CrossRef]

(C) 2019 by the authors. Licensee MDPI, Basel, Switzerland. This article is an open access article distributed under the terms and conditions of the Creative Commons Attribution (CC BY) license (http://creativecommons.org/licenses/by/4.0/). 